\title{
Creation and validation of a visual educational technology content for lactation physiology learning
}

\author{
Criação e validação de conteúdo visual de tecnologia educativa para aprendizagem da fisiologia da lactação
}

Creación y validación del contenido visual de la tecnología educativa para el aprendizaje de la fisiología de la lactancia

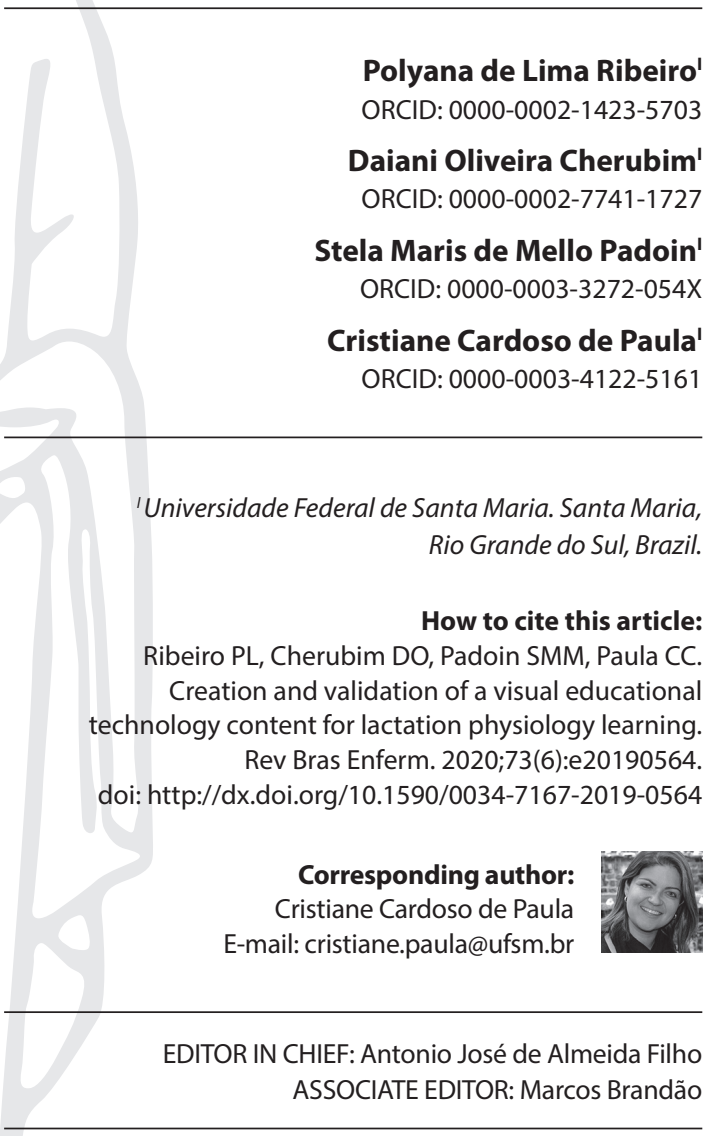

Submission: $07-29-2019$

Approval: 01-23-2020

\section{ABSTRACT}

Objective: to create and validate a visual educational technology content for lactation physiology learning. Method: a methodological study that contemplated the stages of content creation and validation guided by the conceptual model of Knowledge Translation into action. The creation took place in partnership with the educational technology center of the project's home institution. The validation was attended by 27 judges with experience in the obstetric neonatal, pediatric or maternal and child areas and in the theme of breastfeeding. Results: an educational technology covered animation and video techniques to locate, respectively, elements of lactation physiology and the population involved. An Overall Content Validity Index of 0.84 was obtained. Conclusion: the visual educational technology for lactation physiology learning has been validated in content as a tool to introduce the theme and mediate health education actions that can have a positive impact on breastfeeding.

Descriptors: Lactation; Educational Technology; Translational Medical Research; Audiovisual Resources; Health Education.

\section{RESUMO}

Objetivo: criar e validar o conteúdo visual de uma tecnologia educativa para aprendizagem da fisiologia da lactação. Método: estudo de abordagem metodológica, que contemplou as etapas de criação e validação de conteúdo guiadas pelo modelo conceitual da Tradução do Conhecimento à ação. A criação ocorreu em parceria com o núcleo de tecnologia educativa da instituição de ensino de origem do projeto. A validação teve participação de 27 juízes com experiência na área obstétrica, neonatal, pediátrica ou materno-infantil e no tema aleitamento materno. Resultados: a tecnologia educativa abrangeu técnicas de animação e vídeo para localizar, respectivamente, elementos da fisiologia da lactação e população envolvida. Obteve-se Índice de Validade de Conteúdo Global de 0,84. Conclusão: a tecnologia educativa visual para aprendizagem da fisiologia da lactação foi validada em conteúdo como ferramenta para introduzir o tema e mediar ações de educação em saúde podendo repercutir positivamente no aleitamento materno.

Descritores: Lactação; Tecnologia Educacional; Tradução do Conhecimento; Recursos Audiovisuais; Educação em Saúde.

\section{RESUMEN}

Objetivo: crear y validar el contenido visual de una tecnología educativa para aprender la fisiología de la lactancia. Método: estudio del enfoque metodológico, que contempló las etapas de creación y validación de contenidos guiados por el modelo conceptual de la Traducción del Conocimiento en acción. La creación se llevó a cabo en asociación con el centro de tecnología educativa de la institución de origen del proyecto. A la validación asistieron 27 jueces con experiencia en la área obstétrica, neonatal, pediátrica o materna e infantil y en el tema de la lactancia materna. Resultados: la tecnología educativa incluyó técnicas de animación y video para localizar, respectivamente, elementos de la fisiología de la lactancia y la población involucrada. Se obtuvo un Índice de Validez de Contenido Global de 0,84. Conclusión: la tecnología educativa visual para aprender la fisiología de la lactancia ha sido validada en contenido como una herramienta para presentar el tema y mediar en acciones de educación sanitaria que pueden tener un impacto positivo en la lactancia materna.

Descriptores: Lactancia; Tecnología Educativa; Pesquisa Medica Translacional; Recursos Audiovisuales; Educación en Salud. 


\section{INTRODUCTION}

Human milk (HM) is the ideal food for infants due to its immunological and nutritional properties, as it protects the newborn from infections, diarrhea and respiratory diseases, favoring their growth and healthy development. Additionally, it strengthens the mother-baby bond and reduces the mortality rate in children under five years old ${ }^{(1)}$.

The World Health Organization (WHO) and the Ministry of Health $(\mathrm{MoH})$ recommend maintaining exclusive breastfeeding for children until the first six months of life. After this period, HM supply must be maintained and supplemented with food until the age of two ${ }^{(2-3)}$.

Such recommendation implies the conduct of health professionals, such as nurses, to act in a more interactive and systemic way when identifying factors that interfere with the achievement of breastfeeding ${ }^{(4)}$. Scientific evidence identify the factors that influence the maintenance of breastfeeding for 12 months or more as contextual factors and factors related to some sociodemographic characteristics of mothers ${ }^{(5)}$.

This practice can also be influenced by the historical, social and cultural contexts in which the woman-mother-breastfeeding woman is inserted ${ }^{(6-7)}$. In addition to the family context, previous experiences, psychological aspects, maternal work and breast problems related to breastfeeding also interfere in this practice ${ }^{(8)}$

Based on the aforementioned factors, it is worth pointing out that knowledge on breastfeeding management must be acquired for it to be successfully maintained for the indicated time, emphasizing that nursing mothers need continuous encouragement and support in this process ${ }^{(9)}$. In other words, in order to promote breastfeeding (BF) and minimize possible difficulties that may cause its discontinuity, it is necessary for the health team to be attentive to support the mother in the lactation process. It is essential for professionals to play the role of welcoming mothers and babies, being available to listen and prepared to guide, clarify doubts and reduce distress ${ }^{(10)}$.

In order to mediate the interaction between professionals and the population, technological resources are identified as a device that facilitates the understanding of information, and aims at the joint appropriation of knowledge among peers in an accessible way ${ }^{(11)}$. Technologies aimed at health education are tools, processes or materials created to broaden the possibilities of professionals in performing care-producing practices and, consequently, to improve the quality of the health care provided ${ }^{(12)}$.

Moreover, audiovisual resources can be mentioned as a process that facilitates teaching and learning, by providing greater content retention, as individuals absorb information from the stimulus of the visual and auditory memories ${ }^{(13-15)}$.

\section{OBJECTIVE}

To create and validate the visual content of an educational technology for learning the physiology of lactation.

\section{METHODS}

\section{Ethical aspects}

The present study followed the ethical precepts established in Resolution 466/2012, of the Brazilian National Health Council
(Conselho Nacional de Saúde), and has the approval of the Research Ethics Committee of the Federal University of Santa Maria.

\section{Study design, location and period}

This is a study with a methodological approach, guided by the Conceptual Framework of Knowledge Translation into action $(\mathrm{KT})^{(16-18)}$. This model aims to translate and adapt the knowledge obtained through research in an accessible way to the population (target audience or knowledge user), such as professionals and/or managers and/or users. Knowledge Translation seeks to fill the gap between theory and practice in a dynamic process that comprehends the synthesis, dissemination and exchange of knowledge, and may even include the development of tools to improve health. The movement between creation and application of knowledge can be developed independently or interactively, since both integrate a cyclical model with different phases.

This study included the creation of the visual content of the educational technology (ET) and the content validation by technical-scientific expert judges (Figure 1).

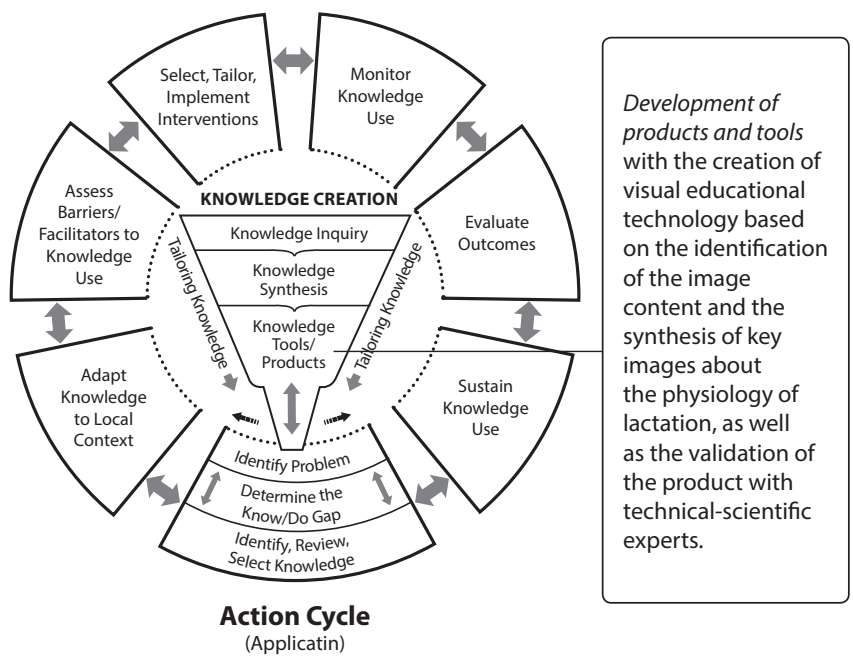

Source: adapted from Straus Graham and Tetroe ${ }^{(18)}$

Figure 1- Schematic picture of the process of creation and application of knowledge, creation stages highlighted, Santa Maria, Rio Grande do Sul, Brazil, 2019

The other stages of the creation cycle (Knowledge Inquiry and Knowledge Synthesis) were covered in the matrix project entitled "Educational Technology for Lactation Physiology Learning: knowledge translation" (FISIOLAC). The audiovisual ET aims to introduce the content of the physiology of lactation to mediate the learning of the target audience in order to complement the actions of promotion and support to BF. Such technological support can be inserted as an auxiliary resource to health education actions, having a positive impact on the practice of lactation. Firstly, the song content was elaborated, which was validated by 18 judges with an Overall Content Validity Index (CVI) of $0.94^{(19)}$. The lyrics and melody were registered in a notary office.

The ET's visual stage took place from March to November 2018, in partnership with the Educational Technology Center (ETC) of the home institution of the research, responsible for the creation of the video's language and animation. The ETC includes professionals from 
the areas of communication, diagramation and education, who make up an interdisciplinary team that aggregates different knowledge and technical skills, with the purpose of producing media tools and content for didactic and pedagogical use. The ETC team and the research team had eight physical meetings to agree on ideas for the animation to be produced. The technological resources of social media have optimized the communication between the teams.

For the creation of the ET's visual content, recommendations were considered for the construction of audiovisual materials, which is composed by pre-production, production and postproduction $^{(20)}$. The lyrics of the song, with authorization of the composers, grounded the construction of the storyboard, which represents a graphic sequence of the actions, consisting of the ET's script. Adjustments during the production allowed to elaborate the layout of the final product, which was submitted for validation.

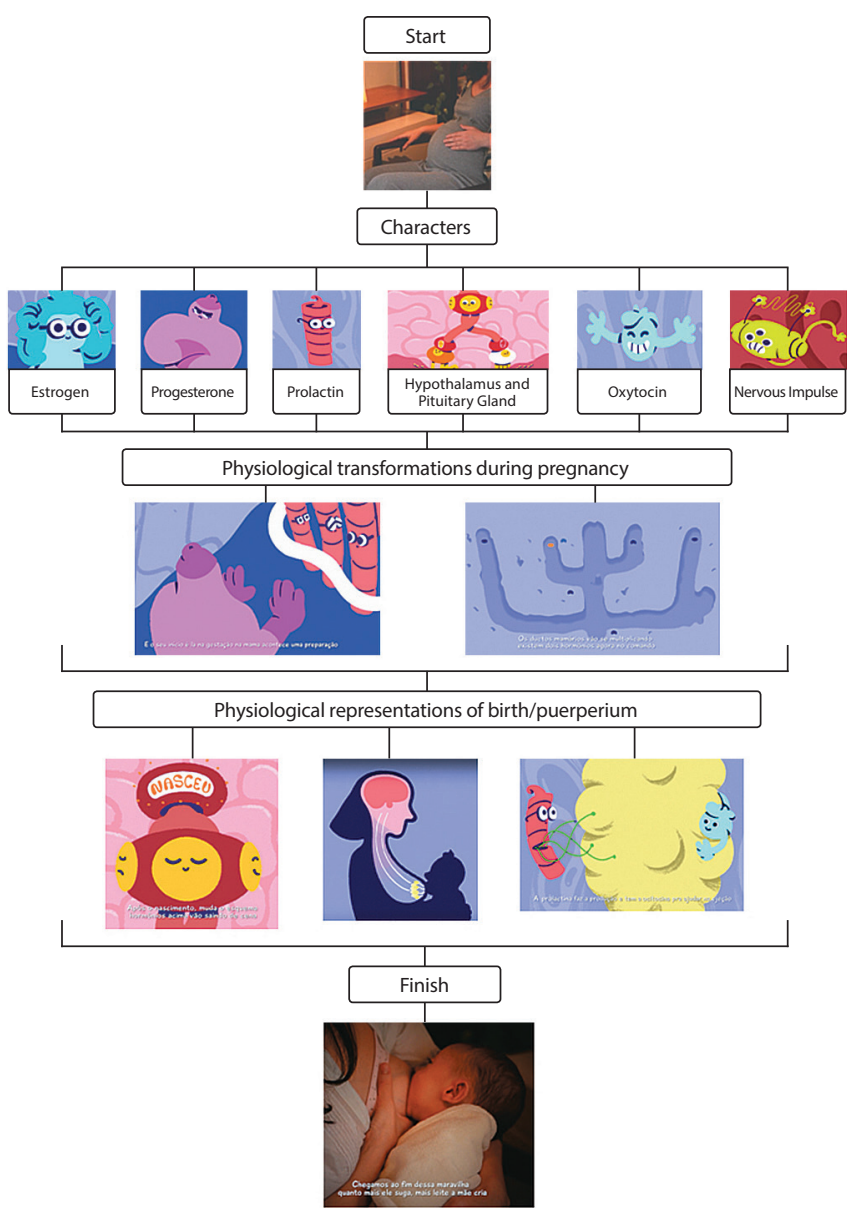

Figure 2 - Flowchart for the synthesis of the Educational Technology for lactation physiology learning, Santa Maria, Rio Grande do Sul, Brazil, 2019

To identify the image content of the key points of lactation physiology, textbooks and manuals from the $\mathrm{MoH}$ were accessed through the Brazilian National Digital Library, the Virtual Health Library and SciELO Books. The following synthesis was considered: HM production is performed physiologically by some hormones and reflexes, among them, mainly, are prolactin and oxytocin. During pregnancy, the process of lactogenesis begins, in which estrogen and progesterone hormones act in the development of ducts and formation of lobes. With delivery, the levels of estrogen and progesterone decrease, generating a progressive increase in prolactin, hormone responsible for milk production. By stimulating the mother's breast, the hypothalamus sends hormones that activate the production of prolactin by the pituitary gland and, at the same time, oxytocin, which comes from the neurohypophysis and helps in the ejection of milk during BF. Therefore, lactogenesis is configured as a process that begins in pregnancy and extends to BF. This process depends on both the maternal physiology and the child's condition ${ }^{(19)}$.

To create the product, other visual technologies about promoting and supporting BF available online, both nationally and internationally, were used as a basis. The ET used video language to locate the population and animation language to represent hormones, nerve impulses and glands.

The visual ET's version submitted for validation corresponds to a video clip that addresses the physiological transformations of lactation from pregnancy to birth, lasting 2 minutes. The first scene fills the starting time of the song (instrumental and melody) with a pregnant woman who waits for the birth of her child with a monthly calendar in her hands, counting the days for delivery. It was recorded in a home environment, showing the preparations of the nursery. In the final scene of the technology, the mother is breastfeeding. Both videos were recorded with permission to use the image. After the scene of the pregnant woman, there is a period of transition from video image to animation. The animation presents six main elements that act in different stages of the lactation process: there is an image representation of hormones - prolactin, oxytocin, progesterone and estrogen -, of the nervous impulse and the hypothalamus (Figure 2).

\section{Sample: eligibility criteria for professionals for the com- position of judges}

The ET was submitted to the validation process in the period from October to November 2018. The selection of participants was by convenience, with 100 nurses, doctors, nutritionists, phonoaudiologists and physiotherapists with experience in assisting, teaching or researching with BF. The construction of a multidisciplinary ET brings together different areas of health, favoring an interdisciplinary articulation and qualifying the product. The invitation to the participants was made via e-mail, WhatsApp and Facebook. Firstly, the judges who were accessed through the International Baby Foods Action Network (IBFAN) and through the International Board of Lactation Consultant Examiners (IBCLC) institute ${ }^{(19)}$ validated the musical content of ET. The snowball technique was used in order to reach greater regional representativeness and involve different health professions ${ }^{(21-22)}$, including indications in the International Child Health Nursing Network (RED ENSI) and in the Educational Technologies Studies Network (RETE - Rede de Estudos de Tecnologias Educacionais).

Initially, the content of the invitation was a scale for auto-fill, which was adapted to the Fehring's Model $(1994)^{(23)}$, seeking to select experts on the theme (maternal-child, obstetric, pediatric and neonatal areas or judges on the theme of BF), from the academic trajectory (master's degree, doctorate, participation in research and scientific production) and professional experience (in maternal and child care, BF counselling). Those who reached a score higher than 5 points advanced to the access of the Informed 
Consent and Confidentiality Terms, the form for identification and characterization of the judges and the tool for assessing the ET content. Sixty-eight professionals did not respond to the invitation and five did not reach the minimum score for the next stage.

The tool for assessing the ET content was a Likert-type questionnaire, with the objective to answer the question (24): "Is the imagery/visual content appropriate to promote lactation physiology learning?"The statements were presented as "totally appropriate", "appropriate", "partially appropriate" or "inappropriate". The criteria evaluated in the form cover the visual content itself, its appropriateness to the lactation physiology, its language, logical sequence and appropriation to the target audience.

\section{Analysis of results and statistics}

To verify the level of agreement of the judges' answers and the ET validation, the Content Validity Index (CVI) test was applied to each question of the form, as well as the Overall CVI, which consists of the sum of the CVI of each statement divided by the number of statements. Items that reached a score equal to or higher than $0.70^{(25-26)}$ were considered valid, given that the greater the number of evaluators, consequently, the lower the agreement index between them ${ }^{(24)}$.

\section{RESULTS}

Judges from all regions of the country were invited, in order to guarantee a national representation and to minimize the existing cultural diversity. Among these participants, 11 were from the Northeast and 11 from the Southeast; the others were from the South (4) and Central-West (1) regions, and there was no response from experts from the North.

Regarding the participants' ages, the minimum was 31 years and the maximum was 68 years. Among them, the predominance was of female participants (24). As for the judges' profession, nursing predominated (19), followed by medicine (4). Additionally, we obtained representatives from the area of nutrition (2), phonoaudiology (1) and physiotherapy (1). Regarding the work experience, it ranged from 4 to 44 years. It is important to highlight that we sought to reach different health professionals to participate in this stage, based on the premise that the work of promotion, protection and support for BF has its guarantee and effectiveness in a multidisciplinary way.

Regarding the participants' practice area, the majority worked in the triad of teaching, research and assistance (11), followed by 8 who worked in teaching. The others identified themselves as active in the area of teaching and research (4), assistance (2), teaching and assistance (1). The predominance of researchers working with teaching is in line with their qualifications, in which everyone, including those who work only in assistance, who are the counsellors in BF, had some type of post-graduate degree. There are 16 judges with doctorate degrees, followed by 6 who had completed a master's degree and 3 with a specialization, and the rest are post-doctorates.

As for the content validation stage, Table 1 shows the result of the assessment of the visual ET by the judges in each statement of the collection tool, as well as the value attributed to the ET's Overall CVI.
Table 1 - Judges' general assessment of the visual Educational Technology to promote lactation physiology learning, Santa Maria, Rio Grande do Sul, Brazil, 2019

\begin{tabular}{|c|c|c|c|c|c|}
\hline Question & $\begin{array}{c}\text { ation ste } \\
4^{*} \\
n(\%)\end{array}$ & n (\%) & $\begin{array}{c}2^{*} \\
N(\%)\end{array}$ & $\begin{array}{c}1^{*} \\
N(\%)\end{array}$ & CVI \\
\hline $\begin{array}{l}1 \text { - Visual content presents } \\
\text { key points about lactation } \\
\text { physiology. }\end{array}$ & $13(48.1)$ & $13(48.1)$ & $1(3.7)$ & - & 0.96 \\
\hline $\begin{array}{l}2 \text {-Visual information on } \\
\text { the lactation physiology is } \\
\text { scientifically appropriate. }\end{array}$ & $12(44.4)$ & $13(48.1)$ & $1(3.7)$ & $1(3.7)$ & 0.92 \\
\hline $\begin{array}{l}\text { 3-There is a logical sequence } \\
\text { of the lactation physiology } \\
\text { presented in the visual content. }\end{array}$ & $13(48.1)$ & $13(48.1)$ & $1(3.7)$ & - & 0.96 \\
\hline $\begin{array}{l}4 \text {-Visual content is presented } \\
\text { clearly. }\end{array}$ & $7(25.9)$ & 14(51.9) & $6(22.2)$ & - & 0.77 \\
\hline $\begin{array}{l}4 \text {-Visual content is presented } \\
\text { understandably. }\end{array}$ & $9(33.3)$ & $13(48.1)$ & $5(18.5)$ & - & 0.81 \\
\hline $\begin{array}{l}\text { 6-Visual language is suitable to } \\
\text { the musical one. }\end{array}$ & $12(44.4)$ & $11(40.7)$ & $4(14.8)$ & - & 0.85 \\
\hline $\begin{array}{l}\text { 7- Image content is adequate in } \\
\text { time to the lyrics of the song. }\end{array}$ & $12(44.4)$ & $12(44.4)$ & $3(11.1)$ & - & 0.88 \\
\hline $\begin{array}{l}\text { 8-The way of presenting the } \\
\text { content in the video is inviting } \\
\text { for those who watch it. }\end{array}$ & $10(37)$ & $13(48.1)$ & $4(14.8)$ & - & 0.85 \\
\hline $\begin{array}{l}9 \text { - It is appropriate for use } \\
\text { with the target audience of } \\
\text { undergraduate students. }\end{array}$ & $15(55.5)$ & $7(25.9)$ & $5(18.5)$ & - & 0.81 \\
\hline $\begin{array}{l}10-\text { It is appropriate for use } \\
\text { with the target audience of } \\
\text { women in the pregnancy- } \\
\text { puerperal cycle. }\end{array}$ & $6(22.2)$ & $13(48.1)$ & $7(25.9)$ & $1(3.7)$ & 0.70 \\
\hline $\begin{array}{l}\text { 11- Image content can promote } \\
\text { lactation physiology learning. }\end{array}$ & $10(37)$ & $12(44.4)$ & $5(18.1)$ & - & 0.81 \\
\hline \multicolumn{5}{|c|}{ Overall CVI calculation } & 0.84 \\
\hline
\end{tabular}

Note: * 4 - Totally Appropriate; 3-Appropriate; 2- Partially Appropriate; 1-Inapropriate; CVI: Content Validity Index.

Chart 1 - Judges' suggestions on the visual Educational Technology to promote lactation physiology learning, Santa Maria, Rio Grande do Sul, Brazil, 2019

\begin{tabular}{|l|l|}
\hline $\begin{array}{c}\text { Suggestions for questions that } \\
\text { had content validity index } \\
\text { lower than } \mathbf{0 . 8 0}\end{array}$ & \multicolumn{1}{|c|}{$\begin{array}{c}\text { Adjustments in the final } \\
\text { version }\end{array}$} \\
\hline $\begin{array}{l}\text { There are more hormones in the } \\
\text { animation than in the lyrics. }\end{array}$ & $\begin{array}{l}\text { The hormones in the lyrics are } \\
\text { maintained. }\end{array}$ \\
\hline $\begin{array}{l}\text { To introduce the characters } \\
\text { initially. }\end{array}$ & $\begin{array}{l}\text { Presentation caption } \\
\text { introduced. }\end{array}$ \\
\hline $\begin{array}{l}\text { In the animation, to adjust the } \\
\text { baby's suckling. }\end{array}$ & $\begin{array}{l}\text { Adjusted the baby's suckling on } \\
\text { the mother's breast. }\end{array}$ \\
\hline $\begin{array}{l}\text { In the initial video, the pregnant } \\
\text { woman looks lonely and worried. }\end{array}$ & Family included. \\
\hline $\begin{array}{l}\text { In the final video, the focus is on } \\
\text { the mother's breast. }\end{array}$ & $\begin{array}{l}\text { Focus expanded to the woman, } \\
\text { baby, family and professionals. }\end{array}$ \\
\hline
\end{tabular}

The technology assessment reached an Overall CVI of 0.84 . This means that the scientific content in its entirety has been validated. It is worth highlighting that two questions had a notably lower CVI value than the other statements, remaining 
above 0.70 , which were analyzed based on the judges' suggestions. One can consider that the analysis and suggestions made contributed to the improvement and quality of the ET. In order to summarize what the comments were, Chart 1 represents the common suggestions about the visual content among the judges. It is worth to note that not everyone who answered the tool by checking items 1 or 2 , "inappropriate" and "partially appropriate", presented suggestions.

The judges pointed out that BF is a complex psychosomatic act, which requires further explanation regarding the conditions of the nursing mother for hormonal release. The authors recognize the complexity of the topic of BF. However, the visual ET in question proposes to introduce the subject of lactation physiology to the BF learning process, inserting itself as an auxiliary resource to health education actions, which may have positive repercussions for the practice of lactation, so it is essential to discuss these implications to complement the ET.

\section{DISCUSSION}

In this study, the techniques used in the ET include video and animation. It is a combination of the lyrics of the song (lactation physiology synthesis) with imagery and visual ideas. The graphic animation or cartoon as a didactic resource for being an interactive support sometimes uses text, sound and image, providing those who watch it with a virtual environment with experiences that stimulate the senses for learning from the visual and auditory memories ${ }^{(27)}$.

In order to develop the ET with quality and methodological rigor, the study was conducted based on the premise that the product was useful and valid in the context in which it was going to be inserted. In this regard, researches developed with the same content as the conceptual framework of KT aimed at translating knowledge for a certain reality, providing benefits to health, teaching and research, and bringing study participants closer to the scientific context ${ }^{(17)}$.

The preparation of the ET started and was conducted based on a script previously established between the research teams and the NTE team. According to Oliveira et al (2010), the script is called Storyboard, and concerns a stage in the development of a learning object. The scenes that compose it are represented in the form of drawings arranged in a sequential manner, similar to a comic book ${ }^{(28)}$. Elaborating the script helps to visualize the final product, and can reduce the production time and eventual errors during the creation process.

When it comes to the creation of an audiovisual technology, it is understood that health professionals need to apply other technical skills, so the assistance of judges in the creation of the tool was necessary ${ }^{(29-30)}$. Researchers point out that, in the multidisciplinary perspective, the objective of creating the technology remains the same, with a different sum of perspectives and methods from different practices. In the present study, the construction of the ET's visual content enabled exchanges beyond the content provided for in the lyrics of the song, as the wisdom of the professionals was shared from discussions about characteristic points of each area of activity, which ensured to broaden the knowledge of those involved throughout this process.
Regarding the technology's validation and analysis, one can consider that studies have been performing these steps with a wide variety of professionals, in order to qualify their product ${ }^{(11-31)}$. We agree with the possibility of inserting in the process of analysis judges with expertise in the teaching, research and assistance triad, considering that this was a factor that contributed to their awareness and approximation with the possibility of using ET in the scope of health education, since ET can bring benefits by promoting content learning(32).

Studies about the incorporation of ET in different scenarios of health practice highlight the social commitment that the researcher assumes so that the use of this technology is ensured in practice. Therefore, particular attention is drawn to the importance of validating the technology before making it available for use in the context for which it was designed. It is important for the use of this tool to remain under assessment and monitoring in order to guarantee quality in its use $\mathrm{e}^{(33-34)}$.

The judges' contribution is an important factor to the improvement of the product, as well as for them to feel more engaged in using technologies in their health practices. Additionally, one should point out the importance of national representativeness for technologies projected for a population with diverse cultures.

It is worth mentioning that the sample number of judges who participated in the validation of the visual technology was significant, and constituted a comprehensive sample for health professionals who work with BF, contemplating the proposal expected for the population of expert judges. The possibility of improving the technology from the opinions of experts from different realities and activities is indicated as an advantage.

\section{Study limitations}

Among the limitations of this study, it is worth pointing out that even with a significant sample number of judges, including health professionals from different sub-areas and activities, other sub-areas were invited, but did not compose the final sample due to lack of response to the invitation. Although this fact indicated the need for a broader selection process of judges, in order to minimize the possibility of small samples, it is known that from a quantitative perspective, a larger sample would result in a lower $\mathrm{CVI}$ than recommended in the research. Another limitation refers to the ET's application/assessment with the target audience, in order to contemplate the cycle of knowledge for the action of the conceptual framework of KT, implying the proposal of other research subprojects linked to the matrix project of the research group.

\section{Contributions to the area}

Knowledge Translation contributed to the creation and validation of the visual ET about lactation physiology, which was configured as a facilitating tool for health education. The use of this technology can assist in health practices by promoting lactation physiology learning in a meaningful and effective way and, thus, bringing professionals and users of knowledge closer together to develop a critical-reflective thinking.

In addition, the use of the visual ET is expected to favor the absorption of content by the target audience in a more precise 
way. The combination of the main characters, represented in a more organic way, with the caption and the song corroborates with a didactic production to promote memorization and assimilation of the presented content.

\section{CONCLUSION}

The visual ET, developed and submitted to content validation, obtained scores above 0.70 . Therefore, it was validated by the judges participating in this study. The stages of content creation and validation were developed in the light of the conceptual framework of Knowledge Translation into action.

One may conclude that the development of the technology, whether in stage of creation or validation, produced a construction of shared and broad knowledge, enabling mutual learning for those involved. The ET's visual content creation provided opportunities for exchanges beyond the content provided for in the tool, since the professionals were able to share their knowledge based on discussions of characteristic points of each area of expertise. The content validation included health professionals who qualified the technology's final version by expressing their opinions for its improvement.

It is worth noting that the resources used for the technology's production were made available by the associated educational institution, with no financial investment in any stage of its development. In order to continue this study, we intend to apply the audiovisual product to teach about lactation physiology with the target audience of women in the pregnancy-puerperal cycle. This next step will aim to contemplate the knowledge cycle for action of the conceptual framework of KT, performing the application cycle.

\section{FUNDING}

This work was carried out with support from the Brazilian Federal Agency for Support and Evaluation of Graduate Education - Brazil (CAPES) - Financing Code 001. Master's degree fellowship awarded to Polyana de Lima Ribeiro.

\section{ACKNOWLEDGMENT}

The authors thank the Educational Technology Center at the Federal University of Santa Maria for the possibility of contributing to this project by creating the video and the animation language of the Educational Technology (ET). Thanks to the research participants who acted as judges with their expertise in the subject, which culminated in the validation of the ET.

\section{REFERENCES}

1. Ministério da Saúde (BR). Secretaria de Atenção à Saúde. Departamento de Atenção Básica. Saúde da criança: aleitamento materno e alimentação complementar. 2 ed. [Internet] Brasília: Ministério da Saúde, DF, 2015 [cited 2019 May 08]. Available from: http://bvsms.saude. gov.br/bvs/publicacoes/saude_crianca_aleitamento_materno_cab23.pdf

2. Ministério da Saúde (BR). Secretária de Política de Saúde. Coordenação Geral de Alimentação e nutrição. Guia alimentar para crianças menores de dois anos - versão para consulta pública. [Internet] Brasília, junho/julho: Ministério da Saúde; 2018 [cited 2019 May 08]. Available from: http://portalarquivos2.saude.gov.br/images/pdf/2018/julho/12/Guia-Alimentar-Crianca-Versao-Consulta-Publica.pdf

3. World Health Organization. Fifty-fourth World Health Assembly. Resolution WHA54.2 - Infant and young child nutrition. Geneva: World Health Organization; 2001.

4. Primo CC, Brandão MAG. Interactive Theory of Breastfeeding: creation and application of a middle-range theory. Rev Bras Enferm. 2017;70(6):1191-8. doi: 10.1590/0034-7167-2016-0523

5. Santana GS, Giugliani ER, Vieira TO, Vieira GO. Factors associated with breastfeeding maintenance for 12 months or more: a systematic review. J Pediatr. 2018;94(2):104-22. doi: 10.1016/j.jped.2017.06.013

6. Marques ES, Cotta RMM, Priore SE. Myths and beliefs surrounding breastfeeding. Cien Saude Colet. 2011;16(5):2461-68. doi: 10.1590/ S1413-81232011000500015

7. Primo CC, Nunes BO, Lima EFA, Leite FMC, Pontes MB, Brandão MAG. Which factors influence women in the decision to breastfeed? Invest Educ Enferm. 2016;34(1):198-217. doi: 10.17533/udea.iee.v34n1a22

8. Capucho LB, Forechi L, Lima RCD, Massaroni L, Primo CC. Factors affecting exclusive breastfeeding. Rev. Bras. Pesq Saúde 2017;19(1):108-13. doi: 10.21722/rbps.v19i1.17725

9. Amaral LJX, Sales SSS, Carvalho DPSRP, Cruz GKP, Azevedo IC, Ferreira MAJ. Factors that influence the interruption of exclusive breastfeeding in nursing mothers. Rev Gaúcha Enferm. 2015;36(spe):127-34. doi: 10.1590/1983-1447.2015.esp.56676

10. Almeida JM, Luz SAB, Ued FV. Support of breastfeeding by health professionals: integrative review of the literature. Rev Paul Pediatr. 2015;33(3):355-62. doi: 10.1016/j.rpped.2014.10.002

11. Saraiva NCG, Medeiros CCM, Araujo TL. Serial album validation for promotion of infant body weight control. Rev Latino-Am. Enfermagem. 2018;26:e2998. doi: 10.1590/1518-8345.2194.2998

12. Barbosa EMG, Sousa AAS, Vasconcelos MGF, Carvalho REFL, Oriá MOB, Rodrigues DP. Educational technologies to encourage (self) care in postpartum women. Rev Bras Enferm. 2016;69(3):545-53. doi: 10.1590/0034-7167.2016690323i

13. Galindo-Neto NM, Alexandre ACS, Barros LM, Sá GGM, Carvalho KM, Caetano JA. Creation and validation of an educational video for deaf people about cardiopulmonary resuscitation. Rev Latino-Am Enfermagem. 2019;27:e3130. doi: 10.1590/1518-8345.2765.3130 
14. Lima MB, Rebouças CBA, Castro RCMB, Cipriano MAB, Cardoso MVLML, Almeida PC. Construction and validation of educational video for the guidance of parents of children regarding clean intermittent catheterization. Rev Esc Enferm. USP 2017;51:e03273. doi: 10.1590/ s1980-220x2016005603273.7

15. Dalmolin A, Girardon-Perlini NMA, Coppetti LC, Rossato GC, Gomes JS, Silva MEN. Educational video as a healthcare education resource for people with colostomy and their families. Rev Gaúcha Enferm. 2016;37(spe):e68373. doi: 10.1590/1983-1447.2016.esp.68373

16. Polit DF, Beck CT, Hungler BP. Fundamentos de pesquisa em enfermagem.7. ed. Artmed, Porto Alegre, RS, 2011.

17. Straus SE, Tetroe J, Graham I. Knowledge translation in health care: moving from evidence to practice. 2 Ed. BMJ Books, Wiley-Blackwell. Canadá. 2013.

18. Straus SE, Tetroe J, Graham I. Knowledge translation in health care: moving from evidence to practice. Ed. A John Wiley \& Sons, Itd, Publication. Canadá. 2009.

19. Cherubim DO, Padoin SMM, Paula CC. Musical educational technology for lactation physiology learning: knowledge translation. Rev Bras Enferm. 2019;72(suppl 3):220-6. doi: 10.1590/0034-7167-2018-0528

20. Kindem G, Musburger RB. Introduction to media production: from analog to digital. 3. ed. Boston: Focal Press; 2005.

21. Biernacki P, Waldorf D. Snowball sampling: problems and techniques of chain referral sampling. Sociol. Methods. Res, Thousand Oaks, CA. 1981;10(2). doi: 10.1177/004912418101000205

22. Lawche CH. A quantitative approach to content validity. P Psych. 1975;28:563-75. doi: 10.1111/j.1744-6570.1975.tb01393.x

23. Fehring, R. J. The Fehring Model. Philadelphia: Lippincott, 1994.

24. Alexandre NMC, Coluci MZO. Content validity in the development and adaptation processes of measurement instruments. Cien Saúde Colet. 2011;16(7):3061-8. doi: 10.1590/S1413-81232011000800006

25. Hernández-Nieto RA. Contributions to statistical analysis. Mérida: Universidade de Los Andes; 2002.

26. Dias FSB, Marba STM. The evaluation of prolonged pain in the newborn: adaptation of the EDIN scale for the brazilian culture. Texto Contexto Enferm. 2014;23(4):964-70. doi: 10.1590/0104-07072014002100013

27. Lopes ACCB, Chaves EV. Animação como recurso didático no ensino da química: capacitando futuros professores. Educitec. 2018;4(7). doi: $10.31417 /$ educitec.v4i07.256

28. Oliveira KA, Amaral MA, Bartholo VF. An experience for the definition of storyboard to collaborative development of learning objects. Cienc Cogn [Internet]. 2010 [cited 2019 May 8];15(1):19-32. Available from: http://www.cienciasecognicao.org/pdf/v15_1/m279_10.pdf

29. Guimarães FJ, Carvalho ARLF, Pagliuca LMF. Elaboration and validation of an assistive technology assessment questionnaire. Rev Eletr Enferm. 2015;17(5):302-11. doi: 10.5216/ree.v17i2.28815

30. Costa PB, Chagas ACMA, Joventino ES, Dodt RCM, Oriá MOB, Ximenes LB. Development and validation of educational manual for the promotion of breastfeeding. Rev Rene [Internet]. 2013 [cited 2019 May 08];14(6):1160-7. Available from: http://www.periodicos.ufc.br/rene/ article/view/3732/2952

31. Lima ACM, Bezerra KC, Sousa DMN, Rocha JF, Oriá MOB. Development and validation of a booklet for prevention of vertical HIV transmission. Acta Paul Enferm. 2017;30(2):181-9. doi: 10.1590/1982-0194201700028

32. Pinto ACS, Scopacasa LF, Bezerra LLAL, Pedros JV, Pinheiro PNC. Use of information and communication technologies in health education for adolescents: integrative review. Rev Enferm UFPE. 2017;11(2):634-44. doi: 10.5205/1981-8963-v11i2a11983p634-644-2017

33. Barwick M, Phipps D, Myers G, Johnny M, Coriandoli R. Knowledge Translation and Strategic Communications: Unpacking Differences and Similarities for Scholarly and Research Communications. Scholarly and Research Communication 2014;5(3) doi: 10.22230/src.2014v5n3a175

34. Gahgliardi AR, Kothanri A, Graham ID. Research agenda for integrated knowledge translation (IKT) in healthcare: what we know and do not yet know. J Epidemiol Community Health. 2017;71:105-6. doi: 10.1136/jech-2016-207743 